\title{
INNOWACYJNOŚĆ PRZEDSIĘBIORSTW A PROBLEMATYKA TRANSFERU TECHNOLOGII
}

\author{
Robert Blażlak \\ Politechnika Łódzka \\ Wydział Organizacji i Zarządzania
}

\begin{abstract}
Streszczenie: Innowacyjność jest jednym z kluczowych czynników determinujących konkurencyjność przedsiębiorstw. Zgodnie z obecną polityką innowacyjną Polski rozwój innowacji powinien odbywać się poprzez bezpośrednią współpracę firm z jednostkami naukowymi i badawczo--rozwojowymi. Sytuacja ta wymaga funkcjonowania odpowiedniego ekosystemu innowacji ${ }^{1}$, który między innymi sprosta zapotrzebowaniu firm na możliwe do wdrożenia oraz komercyjnego zastosowania rezultaty projektów badawczych. Stąd celem referatu jest dokonanie analizy poziomu innowacyjności przedsiębiorstw w odniesieniu do uwarunkowań infrastruktury badawczo-rozwojowej w świetle prowadzonych badań własnych oraz danych GUS.
\end{abstract}

Słowa kluczowe: innowacje, innowacyjność, transfer technologii, ekosystem innowacji

DOI: 10.17512/znpcz.2016.2.13

\section{Wprowadzenie}

Innowacyjność przedsiębiorstw, rozumiana jako zdolność przedsiębiorstwa do absorpcji, czyli stałego poszukiwania, wdrażania, a także upowszechniania innowacji (Pomykalski 2001, s. 18), jest niezwykle istotnym czynnikiem rozwoju polskiej gospodarki. Jak podaje Główny Urząd Statystyczny, począwszy od 2011 roku obserwuje się powolny wzrost liczby przedsiębiorstw uznanych za innowacyjne. W 2011 roku innowacyjne przedsiębiorstwa średnio stanowiły 13,84\% wszystkich przedsiębiorstw $\mathrm{w}$ Polsce. $\mathrm{Z}$ kolei $\mathrm{w}$ latach następnych odsetek przedsiębiorstw uznanych za innowacyjne nieznacznie wzrastal - od 14,45\% w 2012 roku do 14,27\% w roku 2014 (GUS, Nauka i technika. Działalność innowacyjna - wskaźniki). Wraz ze przyrostem liczby innowacyjnych przedsiębiorstw w analogicznym okresie wzrostowi uległy również nakłady na działalność innowacyjną w przedsiębiorstwach. Ogólnie w 2010 roku wynosiły one 23757776 tys. zł (GUS, Nauka i technika. Nakłady na działalność innowacyjna w przedsiębiorstwach wg źródet finansowania działalności innowacyjnej i PKD 2007). Analizując dane statystyczne dotyczące

\footnotetext{
1 Według M. Fransmana „ekosystem innowacji” definiuje się jako zbiór powiązań powstałych i zachodzących nie tylko w obszarze organizacji, ale również całego sektora gospodarki, działających w taki sposób, aby dostępne zasoby wiedzy mogły zostać z sukcesem wdrożone na rynek pod postacią produktu. Tak utworzoną grupę powiązań cechuje symbioza nie tylko w zakresie posiadanych zasobów techniczno-technologicznych, w tym wiedzy, ale również w obszarze ponoszonej odpowiedzialności za realizację procesów rozwoju, absorpcji czy komercjalizacji innowacji.
} 
nakładów przedsiębiorstw na działalność innowacyjną, należy stwierdzić, iż z wyjątkiem 2013 roku nakłady te wykazywały tendencje wzrostowe. W 2014 roku suma nakładów na działalność innowacyjną w przedsiębiorstwach wynosiła 24621577 tys. zł, co stanowiło wzrost w stosunku do 2010 roku o 3,64\% (GUS, Nauka i technika. Nakłady na dziatalność innowacyjna w przedsiębiorstwach wg źródel finansowania działalności innowacyjnej i PKD 2007). Oczywiście w tym miejscu należy dodać, że środki własne stanowiły dominującą pozycję w wydatkach przedsiębiorstwa na innowacje. Ponadto według danych GUS w 2014 roku 6,78\% firm innowacyjnych $\mathrm{z}$ sektora usług wprowadziło nowe lub istotnie ulepszone produkty, 3,95\% wprowadziło nowe bądź istotnie ulepszone dla rynku produkty, a 8,39\% tych firm wprowadziło nowe bądź istotnie ulepszone procesy. W analogicznym okresie $12,10 \%$ przedsiębiorstw przemysłowych uznanych za innowacyjne wprowadziło nowe bądź istotnie ulepszone produkty, 6,2\% nowe lub istotnie ulepszone produkty dla rynku, a 12,95\% nowe bądź ulepszone procesy (GUS, Nauka i technika. Przedsiębiorstwa innowacyjne wg rodzajów wprowadzonych innowacji). Z kolei udział produkcji sprzedanej wyrobów nowych bądź istotnie ulepszonych w przedsiębiorstwach przemysłowych w wartości sprzedaży wyrobów ogółem w 2014 roku stanowił 11,62\% przychodów i był niższy w stosunku do 2010 roku o 2,29\% (GUS, Nauka i technika. Udziat produkcji sprzedanej wyrobów nowych/istotnie ulepszonych $w$ przedsiębiorstwach przemystowych $w$ wartości sprzedaży wyrobów ogółem). Jak podaje GUS, w 2014 roku jedynie 6,6\% przedsiębiorstw spośród firm aktywnych innowacyjnie współpracowało w ramach inicjatyw klastrowych lub innej sformalizowanej współpracy (GUS, Nauka i technika. Przedsiębiorstwa przemystowe wspótpracujące w ramach inicjatywy klastrowej lub innej sformalizowanej wspótpracy $w \%$ przedsiębiorstw aktywnych innowacyjnie). Natomiast przedsiębiorstw współpracujących w zakresie działalności innowacyjnej w stosunku do wszystkich przedsiębiorstw było w 2014 roku 5,6\% pośród przedsiębiorstw przemysłowych oraz 3\% wśród firm usługowych (GUS, Nauka i technika. Przedsiębiorstwa, które wspótpracowaty $w$ zakresie działalności innowacyjnej $w \%$ ogółu przedsiębiorstw). Z punktu widzenia problematyki innowacyjności przedsiębiorstw oraz transferu technologii bardzo istotnym elementem jest liczba pozyskanych praw własności intelektualnej oraz zgłoszonych wynalazków. W tym przypadku w 2014 roku zgłoszono 3941 wynalazków oraz uzyskano 2490 patentów. W przypadku zgłoszonych wynalazków wartość ta jest niższa niż w latach 2012-2013 (rok 2012 - 4410 wynalazków, a rok 2013 4237 wynalazków), ale wyższa od liczby wynalazków zgłoszonych w 2010 roku (3203 wynalazków) i 2011 roku (3878 wynalazków). Z kolei w przypadku udzielonych patentów obserwuje się, począwszy od 2010 roku (1385 patentów), sukcesywny wzrost udzielanych ochron prawnych (GUS, Ochrona własności przemystowej w Polsce. Wynalazki krajowe).

Stąd niezwykle istotnym z punktu widzenia poruszanej w artykule problematyki wydaje się być problem realnego wzrostu innowacyjności rodzimych przedsiębiorstw w kontekście zaspokojenia ich zapotrzebowania na innowacje przez regionalne jednostki naukowe i badawczo-rozwojowe, czyli zachodzenia procesów transferu technologii, którego głównymi podmiotami byłyby zarówno rodzime przedsiębiorstwa, jak i jednostki naukowe i badawczo-rozwojowe. 


\section{Uwarunkowania transferu technologii}

$\mathrm{Na}$ potrzeby pracy przyjęto, że za technologię uważa się bezpośrednie i praktyczne zastosowanie nauki w przemyśle lub handlu, gdzie przez naukę rozumie się wyniki podstawowych badań akademickich (patrz Stonehouse i in. 2001, s. 178), co przede wszystkim kojarzone jest $\mathrm{z}$ wdrożeniem do przemysłu wyników prac rozwojowych bądź badań laboratoryjnych, wpływających na produkcję, zarządzanie jakością, marketing, wsparcie techniczne, sprzedaż, zakupy itp. (OECD 2006). Natomiast transfer technologii rozumie się jako transfer nauki i techniki do ewentualnych użytkowników w praktycznie najkrótszym czasie i języku, jaki jest dla nich zrozumiały (Pomykalski 2001, s. 28), który można traktować jako odpłatne bądź nieodpłatne przekazanie firmie technologii opracowanej w placówce badawczej lub firmie innowacyjnej, i jej zastosowanie przez przedsiębiorstwo w celach produkcyjnych (Sosnowska i in., s. 14 i 70).

Ważnym czynnikiem warunkującym przedsiębiorstwom osiągnięcie pożądanego przez nie poziomu absorpcji i dyfuzji innowacji jest wykształcenie w tych organizacjach postaw charakterystycznych dla zarządzania innowacjami, Gdzie zarządzanie innowacjami rozumiane jest jako proces ukierunkowany na ciągły rozwój organizacji poprzez nowe produkty i procesy (Pomykalski 2001, s. 88), a którego narzędzie stanowią strategie $\mathrm{w}$ obszarze innowacji i technologii oraz badań i rozwoju. Dlatego w celu utrzymania pożądanego przez przedsiębiorstwa poziomu innowacyjności niezbędne jest podjęcie decyzji w obszarze rozwoju innowacji, która dotyczy wyboru jednej z poniższych alternatyw (Baruk 2006, s. 140-142):

- Możliwość tworzenia innowacji we własnym zakresie, co oznacza realizację przez przedsiębiorstwo własnych prac badawczo-rozwojowych, prowadzenie działalności wynalazczej i racjonalizatorskiej czy zatrudnianie pracowników nauki.

- Pozyskiwanie innowacji ze źródeł zewnętrznych, co wiąże się z zakupem zewnętrznych usług badawczo-rozwojowych, nowych technologii i technik wytwarzania, czy wręcz nabyciem innego przedsiębiorstwa.

- Połączenie wytwarzania innowacji z zakupami, czyli realizacja wspólnych przedsięwzięć o charakterze innowacyjnym, a także prowadzenie prac badawczo-rozwojowych.

- Kupowanie na potrzeby wytwarzania, co z kolei zmierza do zakupu techniki wytwarzania bądź technologii pod realizowane przez przedsiębiorstwo badania.

Ponadto w obecnej sytuacji rynkowej przedsiębiorstwa powinny być również postrzegane pod kątem nie tylko posiadanych produktów, marek czy zakresu prowadzonej działalności gospodarczej, ale również przez pryzmat posiadanego lub możliwego do pozyskania portfolio technologii. A tym samym istotne jest, czy posiadają one zdolność do prowadzenia działań w obszarze zarządzania technologią, czyli zarządzania innowacjami w zakresie pozyskania wiedzy oraz transferu technologii w celu uzyskania innowacyjnych produktów i usług (Sahlman 2010, s. 16-17).

W literaturze przedmiotu spotyka się również takie podejście do problematyki zarządzania technologią, które wskazuje na to, że zarządzanie technologią powinno 
być jednoznacznie oddzielone od zarządzania w obszarze badań i rozwoju. Albowiem zarządzanie w obszarze $\mathrm{B}+\mathrm{R}$ odnosi się jedynie do problematyki związanej z wykorzystaniem laboratoriów oraz innych operacji prowadzących do powstania technologii. Natomiast zarządzanie technologią koncentruje się na wykorzystaniu technologii w biznesie, co oznacza, że wpływa nie tylko na jej wytworzenie, ale również na jej rozpowszechnienie i oddziaływanie na otoczenie konkurencyjne (National Research Council 1987).

Z problematyką relacji transferu technologii i innowacyjności przedsiębiorstw związane jest również zagadnienie „inteligencji technologicznej” (technology inteligence), które odnosi się do aspektu uznania technologii za ważny czynnik kształtowania strategii przedsiębiorstwa. Według Th. Duranda termin ten jest bardzo szeroki, bowiem na jego znaczenie składają się takie czynności, jak (Durand 2010, s. 25):

- gromadzenie i kompilowanie informacji technicznych,

- przeprowadzanie foresightu technologicznego,

- monitorowanie zależności pomiędzy rozwojem nauki a rozwojem poszczególnych technologii.

Innymi słowy - na inteligencję technologiczną składają się takie czynniki, jak skaning rozwoju technologii, która potencjalnie może okazać się ważna w przyszłości, wycena takiej technologii, mapowanie i analiza obszaru zastosowań nowej technologii, jak też analiza i ocena dokonywanych przez konkurencję wyborów w zakresie technologii wraz z identyfikacją poziomu związanych z nią kosztów oraz zdolnością konkurencji do jej absorpcji również w obszarze własnego zaplecza $\mathrm{B}+\mathrm{R}$. Zagadnienie to dotyczy również eksploracji baz danych patentów, licencji oraz prowadzenia badań, śledzenie rynków i kanałów transferu technologii, monitorowanie rozwoju teorii strategii opartych na technologii, np. strategii w obszarze organizacji klastrów, grup produktowych czy rynków otwartych innowacji na każdym poziomie organizacji (Durand 2010, s. 25). Stąd termin inteligencji technologicznej obejmuje swoim zakresem również obszar zarządzania wiedzą, możliwości oraz konkurencyjności przedsiębiorstwa i można go uznać za pochodną procesów innowacji zachodzących w przedsiębiorstwie, których efektem jest nowy produkt bądź każda inna innowacja implementowania w struktury przedsiębiorstwa.

Dlatego w przypadku rozwoju czy transferu i absorpcji nowych technologii zarówno przedsiębiorstwo, jak i jednostka naukowa i badawczo-rozwojowa powinna koncentrować swoją uwagę na (opracowanie własne na podstawie: Lütolf-Carroll 2009, s. 4-14):

- analizach rynku i trendach,

- możliwości nawiązania współpracy z innymi podmiotami w obszarze organizacji sieciowej bądź grupy produktowej,

- ochronie własności intelektualnej,

- analizie wartości tworzonej bądź absorbowanej technologii,

- wpływie na obecny i przyszły model biznesu przedsiębiorstwa.

Kolejnym, niezwykle istotnym czynnikiem wpływającym obecnie na relacje między poziomem uwarunkowań transferu technologii a poziomem innowacyjności przedsiębiorstw jest odpowiednia polityka w zakresie rozwoju przedsiębiorstw 
poprzez innowacje. Daje ona z jednej strony wsparcie przedsiębiorstwom w obszarze najbardziej poszukiwanego czynnika warunkującego zaangażowanie się firm w proces rozwoju bądź transferu nowych technologii, jakim są zewnętrzne źródła finansowania w postaci Funduszy Europejskich. Z drugiej, poprzez wspomniane źródła finansowania, aktywnie wspiera rozwój infrastruktury naukowej i badawczo-rozwojowej zlokalizowanej w regionalnych ekosystemach innowacji. Według M.G. Russell (Russell i in. 2011, s. 5) podejście ekosystemowe wykorzystuje się celem opisania wieloaspektowej natury innowacji uwidaczniającej się na wielu różnych poziomach - krajowym, regionalnym, technologicznym i sektorowym, a także przedstawienia złożoności procesu innowacji, od powstawania odpowiednich zasobów wiedzy, aż do jej transferu i dostosowania do potrzeb przemysłu zgodnie z modelem Triple Helix - czyli relacji pomiędzy przemyłem, szkolnictwem wyższym a organami administracji publicznej. Takie podejście stwarza możliwości klarownej identyfikacji interakcji zachodzących pomiędzy wszystkimi uczestnikami oraz innymi determinantami procesów innowacji, które mają bezpośredni wpływ na rozwój oraz dyfuzję innowacji, jednocześnie wpływając na kształtowanie się modeli biznesu w obszarze kreowania i dostarczania wartości, a także kształtowania kultury organizacji, w tym organizacji sieciowej. Stąd ekosystem innowacji można definiować jako zbiór powiązań zachodzących pomiędzy różnymi podmiotami oscylującymi wokół konkretnego wyzwania, współpracującymi celem dostarczenia kompleksowych rozwiązań (Kastalli, Neely 2013, s. 4). Zasadniczo taki ekosystem tworzony jest przez wszystkie organizacje, których wspólnym celem jest rozwój poprzez innowacje. Ciekawym, z punktu widzenia niniejszego opracowania, punktem postrzegania analizy ekosystemów innowacji jest podejście uwzględniające proinnowacyjną politykę Unii Europejskiej, a także wynikające $\mathrm{z}$ niej konsekwencje $\mathrm{w}$ obszarze kształtowania regionalnych strategii innowacji. $\mathrm{Z}$ tego punktu widzenia przez ekosystem innowacji należy rozumieć zbiór idei, organizacji, polityk i regulacji, które determinują kierunek, wynik, efektywność oraz stopień konkurencyjności wynikający z wdrożenia innowacji. Zadaniem tak zdefiniowanego ekosystemu innowacji jest umożliwienie tworzenia takich rozwiązań, które będą mogły odnieść sukces przede wszystkim w ujęciu globalnym. Stąd, aby można było nakłonić podmioty do wdrażania innowacji i jej promocji, musi zostać stworzone odpowiednie środowisko, które będzie zakładać istnienie kompromisu pomiędzy: prostymi, wydajnymi, konkurencyjnymi a społecznie akceptowalnymi czynnikami. Natomiast sama innowacja powinna być postrzegana jako interaktywny system kreowania wartości (High Level Group on Innovation Policy Management 2013).

W tym miejscu należy dodać, że umiejętnie prowadzona polityka w obszarze innowacji zaowocowała na przestrzeni 4 lat (od 2010 do 2014 roku) prawie dwukrotnym wzrostem liczby jednostek aktywnych badawczo. Jak podaje GUS, ogólnie w 2010 roku jednostek takich było 1767, a w roku 2014 już 3474. Z kolei w sektorze przedsiębiorstwa w 2010 roku funkcjonowały 1233 takie jednostki, a w 2014 roku już 2814 (GUS, Nauka i technika. Jednostki aktywne badawczo wg sektorów wykonawczych). Taki stan rzeczy wydają się potwierdzać również dane dotyczące nakładów wewnętrznych na B+R. Jak podaje GUS, w 2010 roku nakła- 
dy te wynosiły 10416 158,2 tys. zł, a w 2014 roku już 16168 229,3 tys. zł. Z kolei nakłady na środki trwałe kształtowały się w 2010 roku na poziomie 2673 267,4 tys. zł, a w 2014 roku wzrosły do kwoty 4002 643,4 tys. zł. Świadczy to nie tylko o rozwoju aktywności badawczo-rozwojowej, ale również o rozbudowie nowoczesnej infrastruktury, której bezpośrednim zadaniem jest wsparcie procesów rozwoju i transferu technologii.

\section{Wyniki przeprowadzonych badań}

Badania, których wyniki zostały przedstawione i omówione w niniejszym opracowaniu, przeprowadzono wśród przedsiębiorstw produkcyjnych funkcjonujących w takich dziedzinach gospodarki, jak: biotechnologia, mechatronika oraz branża tekstylna między innymi z województwa łódzkiego, które pozyskiwały środki z funduszy wsparcia na działania innowacyjne. Projekt obejmował zrealizowanie badań ankietowych, a głównym ich celem była analiza i ocena współczesnych uwarunkowań transferu technologii $\mathrm{z}$ jednostek sfery $\mathrm{B}+\mathrm{R}$ do przedsiębiorstw. Zakres przeprowadzonych prac obejmował m.in. (opracowanie własne, szerzej na ten temat patrz: Blażlak, Owczarek 2013):

- analizę wykorzystywanej technologii i sposobów jej pozyskiwania,

- analizę barier i korzyści wynikających z dotychczasowych zakupów technologii,

- analizę strategii zarządzania technologią w przedsiębiorstwie,

- analizę innowacyjności przedsiębiorstwa.

$\mathrm{Z}$ dokonanych analiz wynika, że przeważająca liczba przedsiębiorstw $(74,7 \%)$ nie napotkała na żadne bariery związane z zakupem nowych technologii. Dla dużych przedsiębiorstw barierą wynikającą $\mathrm{z}$ zakupu nowej technologii były wymagania związane z pozyskaniem licencji. Problem ten dotyczył $16,1 \%$ dużych podmiotów. Z kolei stosunkowo znaczącą barierą dla mikro $(22,5 \%)$ i małych przedsiębiorstw $(23,5 \%)$ były problemy $\mathrm{z}$ finansowaniem działań $\mathrm{w}$ zakresie zakupu i wdrażania do przedsiebiorstwa nabytej technologii.

Ponadto wszystkie badane przedsiębiorstwa, bez wzglądu na wielkość, prowadziły działania z zakresu monitoringu wykorzystywanego przez konkurencję i liderów rynku technologii. Najczęściej odbywało się to poprzez udział w różnego rodzaju targach krajowych i międzynarodowych. Ten sposób monitorowania technologii preferuje 57,5\% mikroprzedsiębiorstw, 69,7\% małych, 66,4\% średnich i $64,5 \%$ dużych podmiotów objętych badaniem. $Z$ takich źródeł wiedzy na temat technologii, jak uczelnie czy jednostki B+R, korzystało 20,0\% mikro, 16,8\% małych i 30,9\% średnich oraz $22,6 \%$ dużych przedsiębiorstw. $Z$ kolei analizę produktów konkurencji $\mathrm{z}$ punktu widzenia zastosowanej technologii wykorzystywało $45,0 \%$ mikropodmiotów, $41,2 \%$ małych, $50,9 \%$ średnich i 48,4\% dużych firm. W tym miejscu należy dodać, że przeprowadzone badania wykazały, iż niewiele badanych przedsiębiorstw posiadało pełną wiedzę na temat patentów z zakresu wykorzystywanej przez siebie technologii. Dla mikroprzedsiębiorstw wskaźnik ten wynosi $12,5 \%$, dla małych - 10,9\%, średnich - 17,3\% i dla dużych - 3,2\%. Wśród przedsiębiorstw, które przyznały się do braku monitorowania technologii, pierw- 
szeństwo należy do mikro $(20,0 \%)$ i małych $(20,2 \%)$ przedsiębiorstw. Wartość tego wskaźnika dla średnich podmiotów wynosi $10,0 \%$, a dla dużych $-9,7 \%$.

$\mathrm{Z}$ przeprowadzonych badań wynika również, że większość przedsiębiorstw $(65,0 \%)$ posiadających własne zaplecze $B+R$ część badań zleca na zewnątrz. $\mathrm{Z}$ kolei $31,7 \%$ badanych przedsiębiorstw $\mathrm{z}$ własnym zapleczem $\mathrm{B}+\mathrm{R}$ samodzielnie prowadzi badania nad rozwijaniem nowych produktów. Natomiast współpraca przedsiębiorstw posiadających własne zaplecze $\mathrm{B}+\mathrm{R}$ z innymi jednostkami badawczo-rozwojowymi, a w szczególności z uczelniami wyższymi, wygląda katastrofalnie. Taką działalność zadeklarowało tylko 3,3\% badanych przedsiębiorstw.

Co więcej - tylko ponad połowa badanych dużych przedsiębiorstw $(67,7 \%)$ posiadała politykę ochrony własności intelektualnej. W przypadku pozostałych przedsiębiorstw ochrona własności intelektualnej nie była realizowana w sposób wystarczający, dla mikroprzedsiębiorstw wskaźnik ten wyniósł $25,0 \%$, małych $30,3 \%$ i średnich $-42,7 \%$. Natomiast, co istotne, $60,5 \%$ badanych przedsiębiorstw tylko w niektórych przypadkach zabezpieczało zasoby własności intelektualnej. Badane podmioty nie przywiązywały uwagi do inwentaryzacji i wyceny posiadanych zasobów własności intelektualnej, czynności te realizowało zaledwie 16,1\% przedsiębiorstw. Pomimo tego $41,9 \%$ przedsiębiorstw deklarowało posiadanie procedur służących podejmowaniu decyzji, czy dany zasób własności intelektualnej należy chronić, czy też nie. Natomiast zaledwie $4,8 \%$ badanych przedsiębiorstw posiadało procedury i środki finansowe niezbędne do prawnego zabezpieczenia własności intelektualnej.

$\mathrm{Z}$ punktu widzenia poruszanej w niniejszym referacie problematyki istotne jest również to, że $42,3 \%$ badanych przedsiębiorstw posiadało plan strategiczny działań innowacyjnych opracowany na podstawie trendów rynkowych, obserwacji działań konkurencji i rozwoju nowych technologii. Z kolei 15,0\% przedsiębiorstw posiadało plan strategiczny uwzględniający przyszłe zmiany w branży, ale nie przydzielało jakichkolwiek zasobów finansowych na innowacje. Natomiast 23,3\% przedsiębiorstw na podstawie opracowanej strategii określa średnio- i długoterminowe cele oraz przydziela zasoby finansowe na innowacje. Niestety, wśród badanych podmiotów 19,3\% przyznało się, że nie posiada planu strategicznego odnośnie działań innowacyjnych.

Wart odnotowania jest również fakt, że badane przedsiębiorstwa najczęściej współpracowały $\mathrm{z}$ innymi podmiotami na etapie zakupu linii produkcyjnych $(29,7 \%)$ i prowadzenia badań naukowych i prac rozwojowych $(20,0 \%)$. Z kolei dla zakupu wyników badań naukowych wartość wskaźnika wynosiła 9,7\%. Niestety prawie czterdzieści procent badanych przedsiębiorstw przyznało się do braku jakichkolwiek działań współpracy z innymi podmiotami. Natomiast ciekawe jest to, że badane przedsiębiorstwa przygotowujące się do kolejnych inwestycji w innowacje ich realizację będą opierały o własny dział badawczo-rozwojowy (28,3\%), współpracę z zagranicznym $(22,3 \%)$ i krajowym $(16,7 \%)$ producentem maszyn i urządzeń, współpracę z krajowymi $(19,3 \%)$ i zagranicznymi $(7,7 \%)$ jednostkami badawczo-rozwojowymi i naukowymi. 


\section{Podsumowanie}

Podsumowując prowadzone w referacie rozważania na temat relacji innowacyjności przedsiębiorstw do uwarunkowań transferu technologii, należy jednoznacznie stwierdzić, że relacja ta odniesie sukces, jeśli uda się w pełni wykorzystać szansę, jaką dają programy oraz polityka UE w zakresie wsparcia rozwoju firm poprzez innowację. Ponieważ wskazuje się w niej przede wszystkim na rozwój regionalnej infrastruktury badawczej pod kątem możliwości transferu i dyfuzji nowych technologii do przemysłu funkcjonującego $\mathrm{w}$ danych regionie, szczególnie jeśli chodzi o obszar specjalizacji inteligentnych i kluczowych technologii. Dodatkowo powinno się zaadaptować na rodzimy grunt doświadczenia krajów skandynawskich, które z powodzeniem wykorzystują zarówno metody Top-Down zawierające elementy strategii UE w zakresie badań i technologii (metoda S\&T - Science \& Technology) oraz metody Bottom-up, czyli analizy potrzeb organizacji, ze szczególnym uwzględnieniem potencjału inteligentnych specjalizacji oraz branż wspomagających, a także jednostek sfery $\mathrm{B}+\mathrm{R}$, i w oparciu o identyfikację tych potrzeb kształtowanie polityki w zakresie rozwoju firm poprzez innowacje przy jednoczesnym kształtowaniu właściwego im ekosystemu innowacji.

\section{Literatura}

1. Baruk J. (2006), Zarzadzanie wiedza i innowacjami, Wydawnictwo Adam Marszałek, Toruń.

2. Blażlak R., Owczarek K. (2012), Współczesne uwarunkowania transferu technologii, „Management", vol. 16 , no. 1, s. 694-708.

3. Blażlak R., Owczarek K. (2013), Modele transferu technologii, Wydawnictwo Politechniki Łódzkiej, Łódź.

4. Blażlak R., Pomykalski A. (2015), Regionalne uwarunkowania transferu technologii, „Przegląd Organizacji”, nr 900, s. 11-17.

5. Cooper R.G., Edgett S.J. (2007), Generating Breakthrough New Product Ideas, Product Development Institute, Toronto.

6. Durand Th. (2010), Technology Intelligence, [w:] Narayanan V.K., O'Connor G.C. (eds.), Encyclopedia of Technology and Innovation Management, Wiley-Blackwell, Oxford.

7. Fransman M. (2014), Models of Innovation in Global ICT Firms: The Emerging Global Innovation Ecosystems, JRC Science and Policy Report, University of Edinburgh.

8. GUS, Nauka i technika, działy: Działalność innowacyjna - wskaźniki, Jednostki aktywne badawczo wg sektorów wykonawczych, Przedsiębiorstwa innowacyjne wg rodzajów wprowadzonych innowacji, Udziat produkcji sprzedanej wyrobów nowych/istotnie ulepszonych $w$ przedsiębiorstwach przemystowych $w$ wartości sprzedaży wyrobów ogótem, Przedsiębiorstwa przemysłowe wspótpracujace $w$ ramach inicjatywy klastrowej lub innej sformalizowanej wspótpracy $w \%$ przedsiębiorstw aktywnych innowacyjnie, Nakłady na działalność innowacyj$n a w$ przedsiębiorstwach wg źródel finansowania działalności innowacyjnej i PKD 2007, Przedsiębiorstwa, które wspótpracowaty $w$ zakresie działalności innowacyjnej $w$ \% ogótu przedsiębiorstw, Bank Danych Lokalnych, https://bdl.stat.gov.pl (dostęp: 10.03.2016).

9. GUS, Ochrona własności przemystowej w Polsce. Wynalazki krajowe, Bank Danych Lokalnych, https://bdl.stat.gov.pl (dostęp: 10.03.2016).

10. High Level Group on Innovation Policy Management, Reports \& Recommendations, June 2013. 
11. Kastalli I.V., Neely A. (2013), Collaborate to Innovate. How Business Ecosystems Unleash Business Value, University of Cambridge, Cambridge.

12. Lütolf-Carroll C. (2009), From Innovation to Cash Flows, John Wiley \& Sons, New Jersey.

13. National Research Council (1987), http://sites.nationalacademies.org/NRC/index.htm (dostęp: 17.01.2011).

14. Sahlman K. (2010), Elements of Strategic Technology Management, Department of Industrial Engineering and Management, University of Oulu.

15. Stonehouse G., Hamill J., Campbell D., Purdie T. (2001), Globalizacja strategia i zarządzanie, Felberg SJA, Warszawa.

16. OECD (2006), The Linkages between Open Services Markets and Technology Transfer, OECD Trade Policy Papers No. 29, 27.01.2006, www.oecd.org (dostęp: 10.03.2016).

17. Pomykalski A. (2001), Zarzadzanie innowacjami, Wydawnictwo Naukowe PWN, Warszawa.

18. Russell M.G., Still K., Huhtamaki J., Yu C., Runens N. (2011), Transforming Innovation Ecosystems through Shared Vision and Network Orchestration, Triple Helix IX Scientific Confernce, http://www.leydesdorff.net/th9/3NWAFYZH9_Russell.pdf (dostęp: 20.04.2015).

19. Sosnowska A., Łobejko S., Kłopotek A., Brdulak J., Rutkowska-Brdulak A., Żbikowska K. (2005), Jak wdrażać innowacje technologiczne $w$ firmie. Poradnik dla przedsiębiorcy, PARP, Warszawa.

\title{
INNOVATIVENESS OF ENTERPRISES AND TECHNOLOGY TRANSFER ISSUES
}

\begin{abstract}
Innovativeness is one of the key factors determining the competitiveness of enterprises. According to the current Polish Innovation Policy, innovation should take place through direct cooperation of companies with universities and others $R \& D$ institutions. This situation requires the proper functioning innovation ecosystem, which inter alia meet the needs of companies for the results of research projects which are possible to implementation and ready to commercial application. The purpose of this paper is to analyse the level of innovativeness of companies with respect to the conditions of research infrastructure in the light of own study and the data of Central Statistical Office of Poland.
\end{abstract}

Keywords: innovation, innovativeness, technology transfer, innovation ecosystem 